\title{
Access to Cable Television: A Critique of the Affirmative Duty Theory of the First Amendment
}

Cable television has been heralded as a great opportunity for the public to receive programming both directly responsive to community needs and truly diverse in content. ${ }^{1}$ This optimisin steins from the technological capability of cable to deliver inany more channels into the home than has been available over the unaided airwaves. ${ }^{2}$ To take advantage of this capability, some legal commentators have favored government regulation requiring cable operators to provide facilities for community oriented programming througli "access cliannels" that would be available to the public at little or no cost. ${ }^{3}$

Proponents of cable access channels have sought to justify requiring such channels by employing the "affirmative duty theory"4 of the first amendment. The affirmative duty theory posits that the first amendment requires the government to encourage the presentation of diverse ideas in the media. The Supreme Court arguably supported such a theory in a decision that allowed content regulation of the broadcasting industry by the Federal Communications Commission (FCC). ${ }^{5}$ This decision recognized the government's authority to grant or deny broadcasting licenses on the basis of the FCC's judgment of which broadcasters would present the greatest diversity of ideas, and thereby best serve the public. ${ }^{6}$ The Supreme Court reasoned that the government's power to limit broadcasting licenses on the basis of diversity is justified because of the scarcity of available broadcast channels. ${ }^{7}$ Legal commentators have smce advocated judicial recognition or legislative implementation of this affirmative duty theory. ${ }^{8}$ Although prece-

1. Note, Access and Pay Cable Rates: Off-Limits to Regulators After Midwest Video II?, 16 Colum. J.L. \& Soc. Probs. 591, 591 (1981) [hereinafter cited as Note, Access and Pay Cable Rates].

2. See infra note 11 and accompanying text.

3. See Barnett, State, Federal, and Local Regulation of Cable Television, 47 Notre DaMe Law. 685, 737-50 (1972); Comment, Public Access to Cable Television, 33 Hastings L.J. 1009, 1010, 1038-43 (1982) [hereinafter cited as Comment, Public Access].

4. See Barron, Access to the Press - A New First Amendment Right, 80 Harv. L. Rev. 1641, 1654-55 (1967); Comment, Public Access, supra note 3, at 1040.

5. Red Lion Broadcasting Co. v. FCC, 395 U.S. 367, 392 (I969).

6. Id.; see infra notes 75-82 and accompanying text.

7. 395 U.S. at $391,400-01$.

8. See Barron, supra note 4, at 1667-69 (advocating judicial recognition); Comment, Public Access, supra note 3, at 1042-43 (advocating legislative implementation). 
dent suggests that such access requirements would probably violate the first amendment if they were imposed on newspapers, ${ }^{9}$ the Supreme Court has not considered whether access requirements could be constitutionally imposed on the cable industry.

This Comment will argue that the affirmative duty theory should not be extended beyond broadcasting to cable, and that any attempt by federal, state, or local government to impose such a duty on cablecasters is contrary to the first amendment. Part I discusses the existing law on cable television. Part II reviews the evolution of the affirmative duty theory in inedia regulation. Part III argues that the "scarcity rationale," which justified carving out an affirmative duty exception for broadcasting, does not apply to cable. Finally, Part IV argues that there are no persuasive policy justifications for applying the affirmative duty to the cable industry.

I

\section{Development and Regulation of Cable Television SYSTEMS}

\section{A. Development of Cable Systems}

Cable television began in the 1940's as a community superantenna service. It amplified and increased the quality of television signals in remote or mountainous regions where such signals would otherwise be received poorly, if at all. The antenna picked up local and distant signals and transmitted them via coaxial cable or microwave to television sets im imdividual homes for a fee. ${ }^{10}$

Modern cable systems do far inore than provide improved reception for nearby television stations. The newest cable systems are technologically capable of providing subscribers with over 100 channels, though many current systems have actual capacities of only twelve or fewer channels. ${ }^{11}$ In addition to providimg their subscribers with strong signals from all local television stations, cable systems will generally offer special channels for a fee, such as Home Box Office, Showtime, and Cinemax. ${ }^{12}$ Furthermore, cable systems may "cablecast" or origi-

9. Miami Herald Publishing Co. v. Tornillo, 418 U.S. 241, 258 (1974).

10. See United States v. Southwestern Cable Co., 392 U.S. 157, 163 (1968). For more imformation on the technology and history of cable, see Report of the Sloan Commission on Cable Commumications, ON the Cable: the Television of Abundance 11-34 (1971).

11. Comment, Public Access, supra note 3, at 1010-11 \& n.15. Cable will eventually include two-way communications, allowing persons to bank by cable, read the daily newspaper on the television screen, and even purchase merchandise shown on the screen. G. CHRISTENSEN, CuRRENT DeVElopments in CATV 47-48 (3d ed. 1973).

12. Id. at 613. Other special cable channels include an all news channel, the Cable News Network, an Entertainment and Sports Programming Network, and an ABC-owned Cable Arts Network. Note, Access and Pay Cable Rates, supra note 1, at 591-93. 
nate their own programs; as a result, the subscriber has many more viewing options than he has on the local television broadcast channels. ${ }^{13}$

Improvement and expansion of the services offered by cable systeins has resulted in a large increase in both the number of cable systeins and the number of subscribers. ${ }^{14}$ From 1975 to 1980 , the number of subscribers increased by sixty percent, and cable industry revenues in 1979 exceeded $\$ 1.8$ billion. ${ }^{15}$ Moreover, the market is far from saturated. About seventy-two percent of households still do not subscribe to cable and numerous communities are still not served at all. ${ }^{16}$

\section{B. Regulation of Cable Systems}

Cable systeins are regulated by local governments, state governments, and the Federal Communications Commission (FCC). Since the cables must be laid underground or strung along overhead telephone poles, a cable system cannot be installed without local government permission. Such permission is usually obtained from the city or county government in the form of a franchise to operate within that commuinty ${ }^{17}$ for a specified number of years. ${ }^{18}$ Regulation of the cable industry also exists on a statewide basis in fifteen states. ${ }^{19}$

The Commumications Act of 1934 gave the FCC authority to regulate "interstate . . . communication by wire and radio" conducted by either common carriers or broadcasters. ${ }^{20}$ Since, unlike radio and television, cable television is not transmitted via the electromagnetic spectrum, ${ }^{21}$ the regulation traditionally exerted by the FCC over broadcasters would not seem to apply. In fact, until 1965, the FCC concluded that the Commumications Act of 1934 did not grant it any authority to regulate cable television. ${ }^{22}$ As cable began to be viewed as

13. Id. at 594. Signals that are not originated locally are sometimes made available by the cable systems' extensive use of satellite transinissions.

14. See Note, FCC Regulation of Cable Television Content, 31 RutGers L. Rev. 238, 242 \& n.26 (1978-79) [hereinafter cited as Note, Regulation of Content]. The recent FCC deregulation of cable has also contributed to cable's boom. See Note, Access and Pay Cable Rates, supra note 1, at 591 n.6.

15. Note, Access and Pay Cable Rates, supra note 1, at 591.

16. There are approximately 4,400 operating cable systems serving almost $28 \%$ of the total number of television households. Comment, Public Access, supra note 3, at 1011 \& n.16.

17. Note, Regulation of Content, supra note 14, at $244 \&$ n.39.

18. Note, Access and Pay Cable Rates, supra note 1, at 615 \& n.174. Most franchises were granted for fifteen years, though grants for twenty to fifty years are not uncommon. Id.

19. Id. at $614-15 \mathrm{n} .173$.

20. 47 U.S.C. $\S 151$ (1976).

21. Note, Regulation of Content, supra note 14, at 241.

22. See CATV and TV Repeater Servs., 26 F.C.C. 403, 427-31 (1959); Note, Regulation of Content, supro note 14, at 243 \& n.32. The Coinmission found that cable operators do not "broadcast" within the meaning of the Act, because the Act defines "broadcasting" as transmission by 
potentially serious competition for television and radio, however, the FCC received increasing pressure from broadcasters to regulate cable. $^{23}$ Accordingly, in 1965 the FCC promulgated signal carriage and nonduplication rules. ${ }^{24}$ The signal carriage rules generally required cable systems to transmit the signals of any station into whose service area the cable brings competing signals, ${ }^{25}$ and the nonduplication rules generally prevented cable operators from airing programs shown on a local broadcasting station for fifteen days before and after the local broadcast. ${ }^{26}$

The FCC's signal carriage and nonduplication rules were challenged on the basis that the FCC did not have the autliority to regulate cable television. The Supreme Court upheld these rules as "reasonably ancillary to the effective performance of the Commission's various responsibilities for the regulation of television broadcasting."27 Since the Communications Act of 1934 has not been amended to give the FCC direct jurisdiction over cable, this "reasonably ancillary jurisdiction" standard apparently still deterinines the extent of the FCC's authority to regulate cable. ${ }^{28}$

\section{FCC Regulation to Promote Programming Diversity}

Once armed with ancillary jurisdiction, the FCC decided to utilize cable's potential for increasing the number of "coinmunications outlets," thereby enhancing the diversity of programming. ${ }^{29}$ In 1969 the FCC extended the fairness doctrine, ${ }^{30}$ the equal time rule, ${ }^{31}$ and spon-

radio, and cable transmits by wire. The Commission declined to find that it could regulate cable transmissions by wire under the common carrier provisions of the Act, title II, because cable subscribers did not select the particular programs they receive. To qualify as a common carrier, the carrier must provide the method of communication for the transmission of the messages chosen by the subscriber. 26 F.C.C. at 427-29.

23. Note, Regulation of Content, supra note 14, at 243.

24. See First Report and Order, 38 F.C.C. 683, 713-15 (1965). It should be pointed out here that the FCC has never attempted to hicense cable systems in a manner similar to the licensing of broadcast stations. See Cable Television Report and Order, 36 F.C.C.2d 143, 207-08 (1972); S. Rivkin, A New Guide to federal Cable Television Regulations 32-35 (1978). The FCC decided that conventional hicensing of cable systems would "place an unmanageable burden on the Commission." 36 F.C.C.2d at 207.

25. Id. at 716-19.

26. Id. at 719-30.

27. Umited States v. Southwestern Cable Co., 392 U.S. 157, 178 (1968); see also Black Hills Video Corp. v. FCC, 399 F.2d 65, 69 (8th Cir. 1968).

28. Note, Regulation of Content, suprá note 14, at 242; see also FCC v. Midwest Video Corp., 440 U.S. 689, 708 (1979) (FCC rules requiring certain cable systems to set aside a number of public access channels held beyond the FCC's ancillary jurisdiction over cable); Home Box Office, Inc. v. FCC, 567 F.2d 9, 34 (D.C. Cir.), cert. denied, 434 U.S. 829 (1977) (FCC's antisiphoning rules for cable exceeded the FCC's ancillary jurisdiction over cable).

29. See Commission Proposals for Regulation of Cable Television, 31 F.C.C.2d 115, 115

30. See infra text accompanying notes 75-78 for a description of the faimess doctrine. 
sorship identification rules ${ }^{32}$ (all of which apphed to broadcasters) to cable operators. ${ }^{33}$ In addition, the FCC required that cable operators with 3,500 or more subscribers origimate some programming from their local studios. ${ }^{34}$ The Commission defended these requirements as necessary for ensuring cable "responsibility" and as desirable for promoting the broadcast of a diversity of ideas. ${ }^{35}$

The FCC requirement that cable operators originate prograinming from their local studios was challenged in court. In United States $v$. Midwest Video Corp. (Midwest Video I) ${ }^{36}$ a plurality of the Supreme Court upheld the origination requirement under the "reasonably ancillary" standard. ${ }^{37}$ Justice Brennan's opinion emphasized that the origination rules would advance the iniportant objective of encouraging diversified programming on television. ${ }^{38}$ In his concurrence, Chief Justice Burger stated that the FCC's rules "strain[ed] the outer limits of ... [its] jurisdietion," but that the Commission should be granted "wide latitude" until Congress said otherwise. ${ }^{39}$

To help achieve the objective of diverse programming, in 1972 the FCC promulgated "access rules." 40 These access rules required cable systems with 3,500 or more subscribers to designate between one and four channels, depending on demand, for specified uses. Assuming a high deinand, one channel was to be devoted to leased access, ${ }^{41}$ one channel each was to be used for educational and local government purposes, and the fourth channel was to provide the public with nondiscriminatory first-come-first-served free access. ${ }^{42}$ The cable operator

31. The sponsorship identification rule states that when a cable operator presents any program for which valuable consideration is promised or received, directly or indirectly, an announcement of who sponsored the program inust be made. See infra note 33.

32. The equal time rule provides that if a cable operator permits any legally qualified candidate for public office to use its cablecasting facilities, it shall afford equal opportunities to all other such candidates for that office to use these facilities. See infra note 33.

33. First Report and Order, 20 F.C.C.2d 201, 223-25 (1969) (current version at 47 C.F.R. $\S \S 76.205-.209, .221(1981))$.

34. Id. at 223.

35. Id. at 208-09.

36. 406 U.S. 649 (1972) (Midwest Video I).

37. Id. at 663 (plurahty opinion).

38. Id. at 668-70.

39. Id. at 676 (Burger, C.J., concurring).

40. Cable Television Report and Order, 36 F.C.C.2d 143, 189-98 (1972). These rules were revised in 1976. Report and Order, 59 F.C.C.2d 294 (1976).

41. See infra text accompanying notes 161-64 for a discussion criticizing the imposition of leasing requirements.

42. See infra text accompanying notes $165-66$ for a discussion criticizing the imposition of nondiscrimmatory first-come-first-served requirements. The four proposed access channel requirements, described in 47 C.F.R. $\$ 76.254-.256$ (1976), were adopted in Report and Order, 59 F.C.C.2d 294, 327-29 (1976) and invalidated in 1979. The channels were to be available to the public free of charge, see infra text accompanying note 44, 47 C.F.R. $\$ 76.256(c)(1)-(2)$ (1976), 
was forbidden from controlling the content of programs aired on any of the four access channels other than to prohibit lottery information and obscene or indecent material. ${ }^{43}$

The access rules were also challenged in court. In FCC v. Midwest Video Corp. (Midwest Video II), ${ }^{44}$ the Supreme Court held that the FCC did not have jurisdiction to require access channels. ${ }^{45}$ The Court rehed on section 3(h) of the Communications Act of 1934, which prohibits the FCC from imposing common carrier restrictions on broadcasters. ${ }^{46}$ The Commission could not, the Court concluded, impose harsher restrictions on cable than it could impose on broadcasters. ${ }^{47}$ However, the decision did not directly rule on the constitutionality of the access rules. ${ }^{48}$ Therefore, the subject of this Comment, the constitutionality of the imposition of access requirements on cable systems based on an affirmative duty theory of the first amendment, remains an open question.

\section{II}

\section{Applicability of the AfFirmative Duty Theory to NEWSPAPERS AND BROADCASTING}

The previous Part described the growth and regulation of cable television, and discussed the important court decisions concerning the FCC's effort to proinote programming diversity im cable. In laying the background for an analysis of the affirmative duty theory of the first amendment's applicability to cable, Part II exanines the seminal broadcasting decisions im which the Court analyzed the application of the affirmative duty theory to two other media: newspapers and broadcasters. In two opinions separated by only five years, the Court decided

except that reasonable charges for equipment and production personnel could be levied for live programs running longer than five ininutes, id. $\S 76.256(\mathrm{c})(3)$.

43. Id. $\$ 76.256(b)$, (d)(3).

44. 440 U.S. 689 (1979).

45. Id. at 708 .

46. 47 U.S.C. $\$ 153(\mathrm{~h})$ (1976). A common carrier service provides nondiscriminatory coinmunication services to all members of the public who choose to use its service. A common carrier must provide its communication services for any use the public desires, regardless of the content of the communication. 440 U.S. at 701 \& nn. 9-10; see infra note 130.

The majority and the dissent in Midwest Video II disagreed as to the nature of $\S 3(\mathrm{~h})$. The majority concluded that $\S 3(\mathrm{~h})$ enbodies Congress substantive determination that broadcasters cannot be compelled to act as common carriers in regard to any portion of their services. Id. at 705 a.15. The dissent, lowever, clained that Congress intended the section to be merely definitional, and thus does not prohibit the FCC from imposing requirements that might be termed a common carrier obligation. Id. at 710-11 (Stevens, J., dissenting).

47. 440 U.S. at 708-09.

48. See infra notes 130-32 and accompanying text for a discussion of language in Midwest Video II that suggested the Court's potential response to a first amendment challenge to access channeI regulations. 
to apply the affirmative duty theory to broadcasters, but not to newspapers. In upholding a regulation that imposed an affirmative duty on broadcasters to present both sides of controversial issues of public importance, the Court reasoned that the scarcity of broadcasting frequencies justifies government encourageinent of diverse programming. This Part will briefly state the history of broadcasting regulation, and then examine these two opimons, Miami Herald Publishing Co. v. Tornillo, ${ }^{49}$ and Red Lion Broadcasting Co. v. FCC, ${ }^{50}$ as well as some related media regulation cases.

\section{A. A Brief History of Broadcasting Regulation}

Until the 1920's, radio was in a state of infancy. The Secretary of Commerce, in charge of issuing radio frequencies to interested parties, was able to grant each applicant a frequency without creating interference. $^{51}$ By 1925, however, there were more private applicants ${ }^{52}$ than frequencies set aside for private use. ${ }^{53}$ When the courts restricted the Secretary's discretion by ruling that he could not deny a license to a qualified applicant merely because the airwaves were getting crowded, ${ }^{54}$ the Secretary could not prevent the ensuing interference as everyone took to the airwaves. ${ }^{55}$

The result was so chaotic that Congress was forced to create the Federal Radio Commission in 1927,56 which was replaced by the Federal Communications Commission in 1934. ${ }^{57}$ Congress delegated to the FCC the authority to regulate all imterstate and foreign communication by wire or radio. Congress also empowered the FCC to grant a license to an applicant for three years ${ }^{58}$ "if [it served] public convenience, interest, or necessity."59 Licenses were to be renewed if the

\footnotetext{
49. 418 U.S. 241 (1974).

50. 395 U.S. 367 (1969).

51. NBC v. United.States, 319 U.S. 190, 210 (1943).
}

52. Prior to World War $I$, all frequencies were used for military and other governmental uses. After the war, some frequencies were allocated for private use under the Wireless Ship Act of 1910, ch. 379, 36 Stat. 629, and the Radio Act of 1912, ch. 287, 37 Stat. 302, repealed, Communications Act of 1934, ch. 652, §602(a), 48 Stat. 1064, 1102 . See generally I E. BARNOUw, A TOWER IN BABEL, A History of Broadcasting IN THE UNITED States 31-33 (1966).

53. $N B C, 319$ U.S. at 211.

54. Hoover v. Intercity Radio Co., 286 F. 1003, 1007 (D.C. Cir. 1923).

55. $N B C, 319$ U.S. at 212.

56. Radio Act of 1927, ch. 169, 44 Stat. 1162 (repealed 1934).

57. Communications Act of 1934 , ch. 652,48 Stat. 1064 (current version at 47 U.S.C. $\S \S 151-$ 757 (1976 \& Supp. IV 1981)).

58. Id. $\$ 307$ (d), 48 Stat. at 1084 . This section was recently amended to extend license terms to five years for television and seven years for radio. Omnibus Budget Reconciliation Act of 1981, Pub. L. No. 97-35, § 1241, 95 Stat. 357, 736.

59. 47 U.S.C. $\& 307$ (a) (1976). 
Commission found that renewal would serve the public interest. ${ }^{60}$

Although Congress authorized the FCC to regulate and license the broadcasting industry, Congress explicitly limited the FCC's power to interfere with free speech. Section 326 of the Communications Act of 1934 states that:

Nothing in this Act shall be understood or construed to give the Commission the power of censorship over the radio communications or signals transmitted by any radio station, and no regulation or condition shall be promulgated or fixed by the Commission which shall interfere with the right of free speech by means of radio communication. ${ }^{61}$

Congress undoubtedly intended that this section prevent the FCC from violating the first amendinent rights of private broadcasting coinpanies. ${ }^{62}$ This section created problems for the FCC and the courts, however, because Congress burdened the FCC with the difficult task of assuring that licenses were granted and renewed in "the public interest" without dictating what particular prograin content was in the "public interest." 63 Not surprisingly, the FCC has significantly involved itself in determining what sorts of programs should be aired, ${ }^{64}$ and the Supreme Court and other courts have, for the most part, upheld the Commission's action. The result, as this Comment shows, has been a dichotomy in the legal treatment of newspapers as opposed to radio and television.

\section{B. The Preferred Constitutional Position of Newspapers}

The preferred constitutional position of newspapers as compared to broadcasters is apparent in the Court's contrasting treatment of riglit to reply statutes in Miami Herald Publishing Co. v. Tornillo ${ }^{65}$ and Red Lion Broadcasting Co. v. FCC. ${ }^{66}$ The Florida statute involved in Tornillo required any newspaper that printed an editorial attack on a political candidate's personal character or official record to offer that candidate the opportunity to publish a reply in the newspaper without charge. A unamimous Court struck down the statute as an unconstitutional abridgment of the freedom of the press. ${ }^{67}$ The Court rejected

\footnotetext{
60. Id. §307(d).

61. Id. $\S 326$ (emphasis added).

62. CBS v. Democratic Nat'l Comm., 412 U.S. 94, 110 (1973).

63. The Communications Act of 1934 provides that "[t]he Commission, if public convenience, interest, or necessity will be served thereby, subject to the limitations of this chapter, shall grant to any applicant therefore a station license provided for by this cliapter." 47 U.S.C. \& 307(a) (1976) (emphasis added).

64. See generally D. Ginsburg, Regulation of Broadcasting: Law and Policy Towards Radio, Television and Cable Communications 107-315 (1979).

65. 418 U.S. 241 (1974).

66. 395 U.S. 367 (1969).

67. 418 U.S. at 258.
} 
Tornillo's argument that the statute did not prevent the Miami Herald from printing anything it wished because the statute "operates as a command in the same sense as a statute or regulation forbidding appellant to publish specified matter." 68 The statute required the newspaper to use valuable space for printing the reply. ${ }^{69}$ This requirement, according to the Court, had a chilling effect on the press; the press' political and editorial coverage would be "blunted or reduced" in order to avoid triggering the statute. ${ }^{70}$

In addition the Court refused to accept Tornillo's arguinent that the pubhic deserved a limited right of access to the press because economic conditions make entry into the newspaper inarket difficult. The Court acknowledged that inost daily newspapers have a monopoly in their area, but then imphicitly rejected Tornillo's argument that this economic circumstance gives rise to a duty to provide public access to the marketplace of ideas. ${ }^{71}$

Tornillo stands in sharp contrast to the Court's decisions regarding government interference with broadcasters' first ainendment interests. The Court has rested this difference in treatment upon the rationale of physical scarcity of broadcast frequencies. In the first Supreme Court case to address the impact of FCC regulations on broadcasters' first amendment rights, $N B C$ v. United States, ${ }^{72}$ the Court stressed that the scarcity rationale limited broadcasters' free speech interests. Radio, the Court said, is a unique mediun of expression in that it "inherently is not available to all." 73 The government was therefore justified in determining who would have the privilege to broadcast. The Court held that denying an applicant a license was not a denial of free speech, at least as long as the FCC granted. licenses only in the public interest, rather than arbitrarily and capriciously. ${ }^{74}$

The Court again relied upon the scarcity rationale when it upheld the constitutionality of requiring broadcasters to coniply with the fairness doctrine ${ }^{75}$ in Red Lion Broadcasting Co. v. FCC. ${ }^{76}$ The fairness

\footnotetext{
68. Id. at 256.

69. Id.

70. Id. at 257 .

71. Id. at $251,257-58$.

72. 319 U.S. 190 (1943).

73. Id. at 226 .

74. Id. at 226-27.

75. 47 C.F.R. $§ \S 73.1910-.1930$ (1981). See generally Simmons, Faimess Doctrine: The Early History, 29 FED. COM. B.J. 207 (1976).

76. 395 U.S. $367,387-88$ (1969). The Court's decision in favor of this media regulation was unanimous, although it should be noted that Justice Douglas did not participate. Curiously, the Court's decision agamst the media regulation statute in Tornillo was also unanimous. For an analysis of the arguable inconsistency between these two cases, see Van Alstyne, The Mobius Strip of the First Amendment: Perspectives on Red Lion, 29 S.C.L. REv. 539, 544-75 (1978).
} 
doctrine has two separate thrusts. One part provides that when a broadcaster allows a commentator to attack or support a candidate, or to attack the imtegrity of any identified person or group, the broadcaster is required to offer an appropriate spokesperson a comparable opportumity to present an alternative viewpoimt over the air. ${ }^{77}$ This part is similar to the right to reply statute struck down in Tornillo. The other portion of the fairness doctrine states that licensees are responsible for presenting botl sides of controversial issues of public importance. ${ }^{78}$

The broadcasters in Red Lion argued that the first ainendinent protected their editorial decisions regarding the content of broadcasts, and therefore allowed them to exclude anyone they pleased from speaking on the air; thus, the fairness doetrine must be unconstitutional. ${ }^{79}$ Despite the Court's acknowledgment that broadcasting is clearly a medium protected by a first anendment interest, the Court would not accept the broadcasters' argument. ${ }^{80}$ The Court held that the scarcity of frequencies justifies the government in forcing licensees to express views not necessarily compatible with the licensees' views. ${ }^{81}$ In a much quoted phrase, the Court said that "[i]t is the right of the viewers and listeners, not the right of the broadcasters, which is paramount."82

Although Red Lion appears to stand for the proposition that government regulation of broadcasting can constitutionally interfere with the editorial discretion regarding content that the Court took great pains to protect in Tornillo, ${ }^{83}$ the inconsistent results of recent Supreine Court opinions regarding the imposition of an affirmative duty to provide some form of access requirements on the broadcasting industry casts doubt upon this proposition.

\section{The Affirmative Duty Theory in Cases Since Red Lion}

A coinparison of the Court's decision in $C B S$ y. Democratic $\mathrm{Na}$ tional Committee $(D N C)^{84}$ with its decision in $C B S$ v. $F C C^{85}$ exeinplifies the inconsistent results of cases involving access regulation of broadcasters. In $D N C$ the Court held that private groups did not have

77. 47 C.F.R. \& 73.1920-.1930 (1981).

78. Id. $\$ 73.1910$.

79. 395 U.S. at 386.

80. Id.

81. Id. at 389. The Court's decision in favor of this media regulation said that when the government allocates a scarce resource, "it is idle to posit an unabridgeable First Amendment right to broadcast comparable to the right of every individual to speak, write, or publish." Id. at 388.

82. Id. at 390.

83. Id. at $386-87$.

84. 412 U.S. 94 (1973).

85. 453 U.S. 367 (1981). 
a right under either the first amendment or the Communications Act of 1934 to buy air time for political advertisements. The Court speculated that at some future date Congress or the FCC would devise a "practical and desirable" form of "limited access," but observed that neither had done so yet. ${ }^{86}$ As compared to the broadcaster, the private citizen cannot be assumed to be the better judge of the importance of his or her own views, the Court claimed. ${ }^{87}$ Moreover, the Court noted that editing is the function of the press "for better or worse." 88 Editors might abuse their power to select material, but the risk of such abuse carmot be eliminated without destroying the protections of free speecl1. ${ }^{89}$

In contrast to this position in $D N C$, where the Court favored editorial discretion over public access, the Court in $C B S$ v. $F C C$ favored candidate access to broadcasting time over a broadcaster's desire to control its own programming. In $C B S$ v. $F C C$ the Court upheld a Congressional statute ${ }^{90}$ that requires broadcasters to sell reasonable amounts of time or allow reasonable access to the broadcasters' facilities by legally qualified candidates for a federal elective office. ${ }^{91}$ Under this access statute, willful or repeated noncompliance can result in FCC revocation of a broadcaster's license..$^{92}$ Before sucli a candidate's campaign begins, the broadcaster may refuse time requests without violating the statute; however, once the campaign has begun, FCC rules require the broadcaster to consider and respond to each request individually ${ }^{93}$ If the candidate files a complaint with the FCC, the licensee must explain its decision to the FCC. The broadcaster must "cite a realistic danger of substantial program disruption . . . or of an excessive number of equal time requests" to avoid incurring the FCC's wrath. ${ }^{94}$

In $C B S$ v. $F C C$, the Carter-Mondale Presidential Committee requested a half hour of prime time to air a documentary in December 1979, eleven months before the national election. ${ }^{95}$ None of the net-

86. 412 U.S. at 131. In Midwest Video II, a later case, the Court declined to treat this speculation as an a priori endorsement of the FCC cable access rules. 440 U.S. at 705 .

87. 412 U.S. at 124.

88. Id

89. Id at $124-25$.

90. Campaign Commumications Reform Act, § 104, 47 U.S.C. § 312(a)(7) (1976).

91. 453 U.S. at 394-97.

92. 47 U.S.C. §312(a)(7).

93. 453 U.S. at 386-87. The factors that the broadcaster must consider include the individual needs of the candidate, the amount of time previously provided to the candidate, potential disruption of regular programining, the number of other candidates likely to invoke equal opportunity rights if the broadcaster grants the request before him, and the timing of the request. CBS v. FCC, 629 F.2d 1, 18-19 (D.C. Cir. 1980), aff d, 453 U.S. 367 (1981).

94. 453 U.S. at 387.

95. Id. at $371 \mathrm{n} .1$. 
works granted the request, ${ }^{96}$ claiming that substantial program disruption would result if they had to sell a half hour of prime time to all presidential contenders. ${ }^{97}$ The Carter-Mondale Presidential Committee filed a complaint with the FCC. The FCC concluded that Carter's campaign had in fact begun within the meaning of the access statute and that the Carter-Mondale time request was not unreasonable. It therefore directed the networks to comply with their statutory duties. ${ }^{98}$ On appeal, the Court of Appeals for the District of Columbia Circuit affirmed the FCC's decision, holding that the access statute did not violate the networks' first amendment rights. ${ }^{99}$

Einphasizimg the need to pay great deference to an agency's interpretation of a statute, ${ }^{100}$ the Supreme Court affirmed. ${ }^{101}$ The Court held that the statute authorized the FCC independently to determine when a campaign had begun. ${ }^{102}$ The Court disagreed with the networks' claim that the access statute as implemented by the FCC violated their first anendment rights by overly restricting their editorial discretion. ${ }^{103}$ In explaining its decision on the first amendment claims, however, the Court did not discuss the statute's effect on editorial discretion. Instead, the Court quoted language from Red Lion which concluded that since a hicensee has no constitutional right to inonopolize a frequency to the exclusion of others, the licensee cannot interfere with the public's interest in appropriate access to the marketplace of ideas. ${ }^{104}$ Therefore, the Court concluded, the proper balancing of first amendment interests among broadcasters, federal candidates and the public required the Court to recognize a limited right of access for federal political candidates. ${ }^{105}$ The Court then summarized its views on editorial discretion without discussion: "[This limited access right] does not impair the discretion of the broadcasters to present their views on any issue or to carry any particular type of programining." 106

The Court's views on editorial discretion were aired briefly in sev-

96. Id. at 373 n.4. CBS responded with an offer to sell two five minute slots, one at 10:55 p.in. (within prime time) and one slot during the daytine hours. $A B C$ indicated that it would sell time in January of 1980 . NBC did not indicate when it would sell time. Id.

97. Id. at 372 n.2, 373 n.4. At the time of the Carter-Mondale request for broadcasting tine, 122 persons had filed notices of candidacy with the Federal Elections Coinmission. Id. at 413 (White, J., dissenting).

98. Id. at 374 (citing Meinorandum Opinion and Order, 74 F.C.C.2d 631 (1979) and Meinorandum Opiniou and Order on Reconsideration, 74 F.C.C.2d 657 (1979)).

99. 629 F.2d 1, 25 (D.C. Cir. 1980), affd, 453 U.S. 367 (1981).

100. 453 U.S. at $382,390$.

101. Id. at 397.

102. Id. at 393-94.

103. Id. at $388,394$.

104. Id. at 395 (quoting 395 U.S. at 389-90).

105. Id. at 396-97.

106. Id. at 397. 
eral other sections of the $C B S$ v. $F C C$ opinion. In one section, the Court decided that the determination of when a campaign begins is not an editorial judgment, but an objective one. ${ }^{107}$ Consequently, the networks cannot complain about losing editorial discretion when the FCC dccides when a campaign has begun. Moreover, the Court stressed that if the networks were allowed a "blank check" to exercise their discretion as they wished, the purpose of the access statute would be eviscerated. ${ }^{108}$ Hence, the Court held that the FCC must be able to enforce and implement the access statute, and held that the FCC's standards were neither arbitrary nor capricious. ${ }^{109}$ The Court distinguished $D N C$ as not having ruled on the statute now before the Court. ${ }^{110}$ The language in $D N C$ statimg the importance of maintaining broadcasters' editorial discretion ${ }^{111}$ was simply not mentioned. ${ }^{112}$

\section{III \\ The Affirmative Duty Theory in Cable: APPLICABILITY OF THE SCARCITY RATIONALE}

As the previous Part has shown, the Court has justified content regulation of broadcastimg because of the scarcity of available "spectrum space." This Part examines the apphicability of the scarcity rationale to cable. It concludes that, although content-neutral regulation of cable is justifiable on the ground that installation of cable creates a significant disruption of the public domain, the scarcity rationale does not apply to cable and does not justify the content regulation of cable by access channel requirements.

While only a small number of broadcasting frequencies can be received in a given locale, the installation of a cable system provides the potential of each household in that locale to receive over a hundred different channels. ${ }^{113}$ This fact has led one comnnentator to conclude that the scarcity rationale developed in $N B C$ and Red Lion is inapplicable to cable systems and that another basis must be found if cable is to be subjected to more restrictive regulation than newspapers. ${ }^{114}$

To date, at least two courts of appeals have agreed with this analy-

107. Id. at 388. The Court's decision in favor of this media regulation, however, neglected to mention that members of the FCC split along party lines in their ruling on the Carter-Mondale

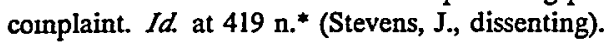

108. Id. at $390 \mathrm{n} .12$.

109. Id. at 390 .

110. Id. at 385-86.

111. See supra notes $84-89$ and accompanying text.

112. 453 U.S. at $385-86$.

113. See supra note 11 and accompanying text.

114. See, e.g., Note, Cable Television and the First Amendment, 71 Colum. L. REv. 1008, 1018 (1971). 
sis. In Home Box Office, Inc. v. FCC, ${ }^{115}$ the District of Columbia Circuit held that the essential precondition of the Red Lion first amendment theory-physical interference and physical scarcity-did not exist in cable systems. ${ }^{116}$ Citing Tornillo as authority for the proposition that scarcity caused solely by economic forces does not justify regulatory intrusion upon the press' first annendinent rights, the court found no evidence showing a constitutional difference between cable and newspapers. ${ }^{117}$ A year later, in Midwest Video II, the Eighth Circuit seeined to agree with the Home Box Office position when it complained in dictum that the FCC had not explained why cable should be regulated when cable is not a scarce commodity. ${ }^{118}$

In contrast to Home Box Office and Midwest Video II, however, the Tenth Circuit's opinion in Community Communications Co. v. City of Boulder ${ }^{119}$ concluded that regulation of cable could be constitutionally sustained on physical scarcity grounds. Boulder involved a local ordinance forbidding the cable coinpany froun expanding its service into nearby unwired communities. The court in Boulder reasoned that cable installation necessarily involves stringing cables along overhead telephone poles or laying theen underground. This process, which is unlike any process related to newspapers, causes a significant disruption of the public domain. ${ }^{120}$ Thus cable, like broadcasting (but unlike newspapers), involves a scarce commodity in that only a limited number of suppliers can serve a given area, ${ }^{121}$ and regulation of the industry is therefore not forbidden under Tornillo but instead is permitted under $N B C$ and Red Lion. ${ }^{122}$

Although Boulder did not involve access channel requirements or

115. 567 F.2d 9 (D.C. Cir. 1977).

116. Id. at 44-45.

117. Id. at 46.

118. FCC v. Midwest Video Corp., 571 F.2d 1025, 1055 (8th Cir. 1978) (dictum), affd, 440 U.S. 689 (1979).

119. 660 F.2d 1370 (10th Cir. 1981), petition for cert. dismissed by agreement, 102 S. Ct. 2287 (1982).

The regulation in question was an ordinance placing a moratorium on Community Communication Company's planned expansion into unwired areas of Boulder. Although the company contended that the inoratorium was the first step towards regulation of prograinming, such as access channel requireinents, the court found that eontention unripe for decision. Id. at 1377 \& n.6.

120. Id. at $1377-78$.

121. Id. at 1378.

122. Id. at 1378-79. The court justified its decision to sustain the regulation by citing broadcasting cases such as DNC and Red Lion. The court did, however, caution that "[t]he conclusion that natural monopoly is a constitutionally permissible justification for some degree of regulation of cable operators does not mean that the full panoply of principles governing the regulation of wireless broadcasters necessarily applies to cable operators." Id. at 1379.

The court also noted that regulation of cable was justified because cable traditionally has been regulated while newspapers traditionally have not. Id. That assertion, however, does no more than beg the question. 
other regulation related to programming content, it can be cited as support for content regulation of cable. Indeed, one commentator has already ventured to carry the reasoning in Boulder that far. The commentator stresses that efforts at awarding dual cable franchises have at times failed because one or both companies declined to install the cable ${ }^{123}$ and argues that cable can be considered a natural inonopoly. Thus, cable can be considered scarce in much the same way as the broadcasting spectrum is deeined scarce, and the same type of content regulation allowed in broadcasting should be permitted in cable. ${ }^{124}$

Boulder's reasoning, however, is flawed. Given that the physical scarcity of broadcast frequencies has justified content regulation of the broadcast industry, it does not follow that an industry causing "sigmificant disruption of the public domain," such as cable or a public utility, can be regulated to the same extent as broadcastimg. ${ }^{125}$ In fact, the Supreme Court held in Consolidated Edison Co. v. Public Service Commission $^{126}$ that the first amendment forbids a state from imposing regulations prohibiting a utility from voicing its views on controversial issues of public importance through public utility bill imserts. Indeed, it appears that there are two classes of state interests that may justify media regulation in general: the need to regulate a natural inonopoly, as in pubhic utilities, and the need to parcel out a resource which is physically scarce, as in broadcasting. Only the latter interest provides a constitutionally permissible basis for content regulation, ${ }^{127}$ but only the former interest is applicable to the cable industry. Boulder found a significant disruption of the public domam in cable since "a cable operator must lay the means of his medium underground or string it across poles in order to deliver his message." 128 That disruption, lowever, is no different from the disruption caused by a teleplione coinpany, a water company, or the power company in Consolidated Edison, which must string telephone lines, lay water pipes, or string power lines. Hence, Boulder's reasoning is flawed to the extent that it suggests that

123. Note, Access and Pay Cable Rates, supra note 1, at 601 n.83.

124. Id.

125. Although Boulder contains language supporting this proposition, the court did not exphicitly rule on the possibility of sustaining content-related regulation. See supra note 122 .

126. 447 U.S. 530 (1980). In that case, the Public Service Commission of New York prohibited the utility from advocating the use of nuclear power in the inserts it mailed to its customers every month with their utility bills. Despite the fact that the disseminator was a privately owned but government regulated monopoly, the Court found that the utility had first amendinent rights: "We have recognized that the speech of heavily regulated businesses may enjoy constitutional protection. Consolidated Edison's position as a regulated inonopoly does not decrease the informative value of its opinions on critical public inatters." $I d$ at $534 \mathrm{n.l}$ (citations omitted).

127. Central Hudson Gas \& Elec. Corp. v. Public Serv. Counı'n, 447 U.S. 566, 567-68 (1980) (monopoly position of a public utility does not remove the first amendinent protection of its commercial speech).

128. Boulder, 660 F.2d at 1377. 
$N B C$ and Red Lion can provide a basis for justifying content regulation of the cable industry. ${ }^{129}$

This conclusion is reinforced somewhat by the Supreme Court's reasoning in Midwest Video II. Although the Court held that the FCC's access channel rules were beyond the FCC's jurisdiction over cable, the Court suggested a potential response to a first amendment claim by focusing on the rules' effect on cable operators' editorial discretion. In its discussion, the Court interpreted section 3(h) of the Communications Act of $1934^{130}$ as incorporating the first ainendment value of preserving private journalistic discretion. The Court stressed that Congress intended that the FCC's regulation of broadcasters would preserve as much of the broadcasters' editorial discretion as possible. ${ }^{131}$ In its view, "the intrusion worked by regulation on the journalistic integrity of broadcasters would overshadow any benefit associated with the resultimg public access." 132 Thus, it is likely that the Court will be inclined to halt any government attempts to impose access channel requirenents, or any other content regulation, on the cable industry.

129. It has also been suggested that cable differs from newspapers in a significant way because newspapers are in the business of presenting news and pohtical commentary, while cable operators, like broadcasters, are in the business of entertaining their clientele. Comment, Public Access, supra note 3, at 1032-33. Distinguishing between media that promote the debate of controversial issues of public importance from those that merely entertain, however, creates insurinountable practical problems. Many works, such as the movie "China Syndrome" (which depicts the dangers of nuclear power plants) or the pohtical satires of the Smothers Brothers, do both. Moreover, the public might even be better informed by an cntertaining drama than by an uninspiring newscast or documentary.

130. 47 U.S.C. $\S 153(\mathrm{~h})$ (1976). That section forbids the FCC from imposing common carrier restrictions on broadcasters. A "common carrier," as the District of Columbia Circuit defined it, is a person who does not "make individualized decisions, in particular cases, whether and on what terms to deal." National Ass'n of Regulatory Utihty Comm'rs v. FCC, 525 F.2d 630, 641 (D.C. Cir.), cert. denied, 425 U.S. 992 (1976).

131. Midwest Video II, 440 U.S. at 704.

132. Id. at 705. The Court also said: "As we see it, § 3(h), consistently [sic] with the policy of the Act to preserve editorial control of programming in the licensee, forecloses any discretion in the Commission to impose access requirements amounting to common-carrier obligations on broadcast systems." Id.

The Court distinguished Midwest Video $I$ on the ground that the origination rules it upheld in the earhier case left editorial discretion over what was cablccast with the cable operator. Id. at 700 . The Court, however, left open the question of whether cable operators are entitled to exactly the same amount of editorial discretion as are broadcasters. Id. at 707 n.17.

Furthermore, the Court rejected the argument that cable operators do not engage in editorial decisions merely because they do not select individual programs or stories to be aired, as contrasted with newspaper and broadcastcr editors; the cable operator largely chooses the "generic character" of the station, such as sports or movies. Note, Access and Pay Cable Rates, supra note 1, at 643. Consequently, the FCC failed in its contention that the access rules do not infringe upon the cable operator's first amendment discretion. The Court coinmented that the cable operator's decisions regarding which services to offer are editorial decisions deserving of constitutional protection. 440 U.S. at 707 n.17. 
IV

Policy ARguments Against ApPlying the Affirmative Duty Theory to Cable

This Part begins by describing the evolution of the movement for increasing diversity in cable. It then examines whether government attempts to increase diversity are necessary or likely to succeed. This Part concludes that an unregulated cable market will create as much diversity as the public desires, and that government is not competent to determine what types of programming the public should receive.

\section{A. The Evolution of the Importance of Diversity}

The rationale for promoting diversity in broadcasting and cablecasting rests upon the belief that the purpose of the first amendment is to "preserve an uninhibited marketplace of ideas in which truth will ultimately prevail." 133 The Supreme Court has concluded that an "uninhibited, robust, and wide-open" debate on issues of public importance enables the public to make the best decisions on how it wishes to be governed. ${ }^{134}$

Origmally, the "marketplace of ideas" rationale centered on the notion that government should tolerate some level of relatively harmless diversity, not that the government should affirmatively promote it. ${ }^{135}$ Government protected speech only by maction, by refusing to engage in censorship or prior restraint. ${ }^{136}$ The early cases that upheld free expression viewed diversity as a tolerable nuisance rather than a desirable good. ${ }^{137}$ Recent commentators, however, argue that the first amendment imposes on government the affirmative duty of encouraging free speech, and thereby promoting diversity. ${ }^{138}$ Without access to wide reaching means of commumication such as the mass media, they argue, the right to free speech is meaningless. ${ }^{139}$ Consequently, government must "undertake positively to promote and encourage freedom of expression, as by furmshing facilities, eliminating distortions in the media of communication, or making information available." 140

133. Red Lion Broadcasting Co. v. FCC, 395 U.S. 367, 390 (1969).

134. New York Times Co. v. Sullivan, 376 U.S. 254, 270 (1964); accord A. MEIKLEJohN, Free Speech and Its Relation to Self-Government 26 (1948).

135. See, e.g., Joseph Burstyn, Inc. v. Wilson, 343 U.S. 495 (1952); Kunz v. New York, 340 U.S. 290 (1951). For an argument that the affirmative duty theory is not supported by an analysis of the first amendment, see Lange, The Role of the Access Doctrine in the Regulation of the Mass Media: A Critical Review and Assessment, 52 N.C.L. Rev. 1, 10-14 (1973).

136. See cases cited in J. Nowak, R. Rotunda, \& J. Young, Handbook on ConstituTIONAL LAW 717 (1978); Barron, supra note 4, at 1642-43.

137. See, e.g., cases cited supra note 135.

138. See, e.g., J. Barron, Freedom of the Press for Whom? at xiii (1973).

139. Note, Cable Television and the First Amendment, supra note 114, at 1021.

140. T. Emerson, The System of Freedom of EXPression 4 (1970). 
Access channel requirements are one method by which government arguably may imcrease the diversity of program offerings on cable. Proponents of such requirements point out that television in general tends to appeal to the tastes of the mass public, while ignoring the more sophisticated segment of the audience. ${ }^{141}$ The reason for this tendency, at least in television, is that the three major networks are engaged in lieated competition to draw the greatest number of viewers. ${ }^{142}$ The networks need large audiences in order to attract advertisers willing to pay the high advertising fees that the networks charge to offset their high production costs and to maximize their profits. Therefore, the econonic incentive is not to appeal to sinaller segments with distmct interests. Consequently, the diversity found in books, magazmes, and movies is absent from television.

Dissatisfaction with this state of affairs is evident in a number of FCC policies. ${ }^{143}$ The FCC has decided that broadcasters should be forced to air more local and public affairs programming. The FCC has stressed that the amount and quality of the broadcaster's public affairs and local programming will be considered when it applies for a new or renewal license. ${ }^{144}$ In a 1960 policy statement, ${ }^{145}$ the FCC imposed on licensees the duty of attempting to meet all the tastes, needs, and desires of their histeners. ${ }^{146}$ The FCC suggested fourteen categories of programs that should be addressed by the licensee, ranging from programs employing local talent to programs aimed at minority groups. ${ }^{147}$ The FCC's prime time access rules ${ }^{148}$ imply a desire to force television stations to broadcast something other than standard network fare durmg the precious prime time hours of 7:00 p.m. to 11:00 p.m. The FCC

141. Note, Cable Television and the First Amendment, supra note 114, at 1024.

142. Id.

143. Recently, however, the FCC has moved toward deregulating the industry. In 1981 , the FCC deregulated radio in some respects. Report and Order, 84 F.C.C.2d 968 (1981). The Commission is also supporting Congressional repeal of the Fairness Doctrine. Broadcasting, Sept. 21, 1981, at 23.

144. See Fidelity Television, Inc. v. FCC, 515 F.2d 684 (D.C. Cir. 1975).

145. Program Policy Statement (Network Programming Inquiry), 25 Fed. Reg. 7291 (1960), reprinted in D. GINSBURG, supra note 64 , at $174-75$.

146. 25 Fed. Reg. at 7295.

147. Id. The categories were (1) opportunity for local self-expression; (2) developinent and use of local talent; (3) children's programs; (4) religious programs; (5) educational programs; (6) public affairs; (7) editorials by licensees; (8) political broadcasts; (9) agricultural programs; (10) news; (11) weather and market reports; (12) sports programs; (13) minority groups programs; (14) entertainment.

148. Second Report and Order, 50 F.C.C.2d 829 (1975), reprinted in D. GinsBuRG, supra note 64, at 266-78. The prime time access rule provides that stations in the fifty largest television markets that are either owned by or affiliated with the networks may not carry more than three hours of network programming during the four prime time liours. Exemptions are made for network news, and waivers are granted for sports runovers and documentary programs such as "Wild Kingdom." Second Report and Order, 50 F.C.C.2d at 829-30, 842-43. 
designed these restrictions to ensure that "the voices of other persons might be heard." 149

Since cable greatly increases the number of channels from which a viewer may choose, commentators have focused on cable's unique potential for improving diversity in television programming. The following passage sums up their hopes for cable television:

[C]able development has the potential of creating an electronic inedium of communications more diverse, more pluralistic, and nore open, more like the print and film media than our present broadcast system. It could provide minority groups, ethnic groups, the aged, the young, or people living in the same neighborlood an opportunity to express, and to see expressed, their own views. ${ }^{150}$

Although diverse programming appears to be a desirable goal ni the abstract, ${ }^{151}$ the specific issue being addressed in this Comment is whether diversity is a goal desirable enough to justify government contpulsion of greater diversity in cable programming and whether the government could indeed achieve this goal if it attempted to do so.

\section{B. Diversity and the Economics of Cablecasting}

As the previous Section has indicated, proponents of access channel requirements support government regulation under the banner of promoting the diversity of ideas broadcast. Implicit in their position, however, is the assumption that diversity will not happen if the cablecasters are left to their own devices. This Section challenges the validity of that assumption, and concludes that economic pressures $\mathrm{n}_{1}$ the cable market will lead to programming diversity, obviating the need for government intervention. ${ }^{152}$

149. Id. at 847. Moreover, hicensees are expected to air programs other than game shows during the period they do not carry network programming. The FCC strongly suggested that programming be addressed to the "special needs of minority groups." Id. at 852 . For criticism of the prime time access rule, see id. at 889-903 (Robinson, Comm'r, dissenting).

150. Cabinet Comm. on Cable Communications, Report to the President 15 (1974).

151. Indeed, one commentator has stated that it is difficult to imagine a persuasive argument against the desirability of diversity. D. GINSBURG, supra note 64, at 294.

152. An argument can be made that cable operators should be required to provide public access on a nondiscriminatory basis to all interested parties because the cable operator's actions are equivalent to state action. See, e.g., Kreiss, Deregulation of Cable Television and the Problem of Access Under the First Amendment, 54 S. CAL. L. Rev. 1001, 1017-18 n.75 (1981); Comment, Public Access, supra note 3, at 1037-38. The granting of a franchise by the state or local govern-ment places the government in a "joimt venture" with the chosen cable operator. Kreiss, supra, at 1017 n.75. However, the fact that a privately owned and operated busmess is subject to extensive and detailed regulation does not necessarily convert private action into state action. Jackson v. Metropolitan Edison Co., 419 U.S. 345, 357 \& $n .17$ (1974) (state must affirmatively approve of a utility's specific act to form state action). Furthermore, a cable company is a disseminator of ideas as well as the provider of an arguably public service, and therefore is entitled to at least some first amendment protection. See CBS v. Democratic Nat'l Comm., 412 U.S. 94, 120 (1973) (three Justices); id. at 134 (Stewart, J., concurring). 
In the cablecasting business, the key to a profitable enterprise is attracting subscribers. This task is inade difficult because new subscribers who had previously paid nothing for the luxury of watching television (although their unaided reception may not have been good) are faced with an initial installation charge as well as a monthly subscription fee. The cable operators must therefore make their offerings worth the price. Consequently, cable operators are likely to offer as many channels with as diverse an offering as possible to attract and retain subscribers. If a cable operator has one hundred channels available, he will attempt to appeal to broad and diverse interests of the public. The result will be wide diversity, somewhat akin to the situation currently existing in the radio market. Radio listeners have many options. Radio stations carry news, talk shows, religious programming, and all types of music, ranging from classical to lard rock to jazz. Even the FCC has adinitted that competition among radio stations has created "an almost bewildering array of diversity" in entertaminent formats alone. ${ }^{153}$ There is no reason to believe that the saine will not occur on cable if normal market forces are allowed to operate. ${ }^{154}$

Despite the probability that diverse cable programming will occur under normal market conditions, commentators interested in diverse programming have advocated that government impose public access channel requirements on the cable industry. ${ }^{15 s}$ One reason for the interest in requirmg access channels on cable is the fear that cable operators are unlikely to voluntarily provide access cliannels where more

153. FCC v. WNCN Listeners Guild, 450 U.S. 582, 590 (1981) (quoting Memorandum Opinion and Order, 60 F.C.C.2d 858, 863 (1976)).

154. See Note, Access and Pay Cable Rates, supra note 1, at 653-54.

One might contend that cable's offerings will not be as diverse as radio's because radio is free to the consumer while cable is not. Therefore, the argument runs, radio can be expected to serve the needs of all members of the public, rich or poor, while cable can be expected to serve only the wealthier segments of society. This argument, however, ignores the fact that magazines and books offer the public as much diversity as does radio, yet the former are not free to the consumer.

Moreover, normal market forces will increase cable diversity because cable programs compete with TV programs for viewers. The networks already are noticing the effects of their compctition with cable offerings. Apparently in response to the success of the Cable News Network, all three networks are planning to add news programs during the hours of 11:30 p.m. and 7:00 a.m. Rosenberg, New Battleground for TV News, San Francisco Chron., Apr. 24, 1982, at 31, col. I.

In addition, the competitive market will probably be increased in the next decade due to lowpower television service. Low-power television stations will have a weaker signal than either UHF or VHF stations, so that their signals will be received in the local area only. These stations therefore will probably serve only the specialized local needs for community-oriented programming. In re An Inquiry Into the Future Role of Low-Power Television Broadcasting and Television Translators in the National Telecommunications System, 45 Fed. Reg. 69, 178 (1980), reprinted in 82 F.C.C.2d 47 (1980). At present, the FCC is studying methods for allocating lowpower television hicenses. See In re An Inquiry Into the Future Role of TV Translators and LowPower Television Broadcasting in the National Telecommunications System, 87 F.C.C.2d 610, 611 (1981).

155. See, e.g., Barnett, supra note 3, at 737-50; see also supra text accompanying notes 40-48. 
money could be made by leasing out the channel or by showing other, more profitable programming on it. ${ }^{156}$ The greater the financial burden that the operator would have to bear-such as providing access users with equipment and lessons free of charge or at discounted rates-the greater the risk that the cable operator would refuse to provide access channels voluntarily. Access channel proponents also fear that cable operators will censor unpopular viewpoints in order to appeal to the widest audience. ${ }^{157}$

These fears may be premature. The anticipated profits from cable systems are sufficient to entice most cable bidders to offer nore than four access channels. ${ }^{158}$ As more cable systems offer a greater number of channels, the probability of cable operators voluntarily providing public access channels increases. If access channels are not offered, it will more likely be due to the cominunity's lack of interest $\mathrm{m}$ watching these programs than to the cable operators' refusal to offer such channels.

While it is uncertain whether the imposition of access channel requirements in general is necessary in view of the possibility of cable operators voluntarily providing such channe's, it is even inore uncertam whether some specifically proposed access channel requirements are necessary, or even helpful at all. One specific proposal is to require cable operators to designate one channel for leased access. ${ }^{159}$ Proponents of such leasing requirements argue that cablecasters will not lease out channels voluntarily because they have no desire to create competition for theinselves by leasing out channels. ${ }^{160}$ Reality, however, seems to point in the other direction. Cable owners currently attract viewers not so much by offering programs that they origmate, as by offering leased pay cable channels such as Hoine Box Office and Showtime. ${ }^{161}$ In fact, cable companies that previously had offered only one pay cable channel because both the cable company and the pay cable channel were subsidiaries of the same company, are voluntarily planning to offer rival pay cable offerings. ${ }^{162}$

In addition, those who herald leasing requirements as the pre-

156. Hammond, The Federal Communication Commission's Cable Accent [sic] Rule and the Fiction of Public Participation, 5 BLACK L.J. 369, 377 (1977).

157. See id. at 376-78; Barnett, State, Federal, and Local Regulation of Cable Television, 47 Notre Dame Law. 685, 740-46 (1972); Note, Toward Community Ownership of Cable Television, 83 Y ALE L.J. 1708, 1716 (1974).

158. Van Deerlm, Student Symposium: Communications Regulation-Introduction, 69 CALIF. L. REv. 446, 449-50 (1981).

159. See, e.g., Barnett, supra note 3 , at 737-38, 745-46; see also supra text accompanying note 41.

160. See, e.g., Barnett, supra note 3 , at 745.

161. See id. at 663 .

162. Id. at 664 n.477, 665 n.480. 
ferred path to programming diversity assume that private producers would jump at the chance to lease cable channels; in fact, however, the current problem with leased access appears to be a shortage of applicants, rather than the refusal of cablecasters to lease. In Manhattan, for instance, franchise provisions require leased access to pay channels, but no one has yet apphed for such a lease. ${ }^{163}$ Until more concrete evidence of refusals to lease channels to interested parties is discovered, government should be wary of innosimg unnecessarily restrictive requirements on cable operators. ${ }^{164}$

Another specific access channel proposal is to require cable operators to designate one channel as a nondiscriminatory first-coine-firstserved free access channel. ${ }^{165}$ However, if the goal of access proponents is to pronote presentation of divergent views, these views might be better received in a format other than such a free access channel. The public might be bored by a host of nonprofessionals talking to a camera in a studio, without skillful production, direction, and editing. Furthermore, the sinall budgets and the lower quahty of equipment used by cable operators as coinpared to television broadcasters contribute to an overall lower quality of progranming, making it even less likely that noncommercial access programs will be popular. ${ }^{166}$ Instead, it inay be preferable to let cable operators experiment with their own forms of public access. Radio and television stations have been offering various types of "public access" programs for years. In a typical radio hosted talk show, for instance, anyone may call in and ask a question or inake a statement. The only censorship of callers is a ban on obscenity and a limit on the tinne accorded each caller. Furthermore, the type of talk show made popular by Phil Donahue has enornous potential for airing public views on controversial issues in an entertaming style. Donahue's prograin not only involves a great variety of guests, but a substantial portion of the show is devoted to letting the general audience ask the guests questions. Hence, cablecasters should not be hamstrung into offering relatively unpopular access channels when alternative forms of public access are not only possible but are likely to be more attractive to the viewing audience.

\section{The Competence of Government to Promote Diversity}

Not only are access channel requirements econonnically unneces-

163. Id. at $665 \mathrm{n} .480$.

164. Id at 663.

165. See, e.g., Barneth, supra note 3, at 740-47; see also supra text accompanying note 42.

166. Note, Access and Pay Cable Rates, supra note 1, at 652-53. Even if the cable owner provides the necessary equipment, cable programming is still expensive. Hammond, supra note 156 , at 376. 
sary, but such requirements may also be unhelpful in promoting diversity, and may in fact discourage diversity. The reason that access regulations inay be unhelpful (or even harmful) for programining diversity is that government is not competent to perform the kind of content regulation needed to further diversity. This Section will argue that, based on the traditional philosophy and the realities of our political system, and based on the federal government's experience in regulating the content of radio and television programs, no government body is suited for the task of determining how the goal of diverse cable programming should be furthered.

The rationale for access channel requirements rests upon the affirmative duty theory of the first amendinent. This theory assumes that government can and should determine what programming is good for the public, even if only a small segment of the public wants to watch the programs. ${ }^{167}$ However, having the government decide what should be aired, and thereby what should be watched, is contrary to our traditional philosophy that speech is not meant to be controlled by the government. ${ }^{168}$

In addition to being contrary to the thrust of the first ainendment, the affirmative duty theory is inappropriate because our political process makes government unsuited for determining diversity. Our democratic political system is majoritarian. If a local city council or state legislature decides what is aired, the unpopular or minority viewpoints are likely to receive hittle air time, if any. As cable programming becomes more diverse and controversial, it is likely that splinter groups will forn to object to one or more of the controversial views. Politicians inay then experience significant pressure froin such splinter groups to censor the cable operators, ${ }^{169}$ which could result in less diverse programming. ${ }^{170}$ Moreover, politicians must satisfy their constituents, and thus will be vulnerable to strident threats of political retribution from powerful interest groups. And if persons selected by the parties make the decisions, their political affiliations inay color their judgment, as illustrated in the FCC decision in $C B S$ v. FCC, where the Commissioners spht strictly along party lincs. ${ }^{171}$ Therefore, it seems

167. D. GINSBURG, supra note 64 , at 318-19. For example, the FCC presumed that its access rules (struck down in Midwest Video II) would greatly beuefit the public, although its own evidence revealed that few people were watching access programs. FCC v. Midwest Video Corp., 571 F.2d 1025, 1045 (8th Cir. 1978) (citing 1976 Report, 59 F.C.C.2d 294, 296 (1976)), affd, 440 U.S. 689 (1979).

168. See, e.g., 571 F.2d at 1046.

169. See McGrew, Whose Right is Righter?, 234 Nation 332, 335 (1982).

170. Id.

171. See supra note 107 and accompanying text. 
unlikely that the pohitical process will yield principled decisions as to programming diversity.

Even worse than the probable lack of principled government decisions on what constitutes diversity, however, is the danger of government acting paternalistically to decrease diversity. The classic example of such government action is FCC v. Pacifica Foundation. ${ }^{172}$ A radio station broadcast a monologue by comedian George Carlin at two o'clock on a weekday afternoon. The monologue was entitled "Filthy Words," and satirized contemporary taboos against "dirty words." A man driving in his car with his fifteen year old son lieard part of the Carlin monologue and complained to the FCC. The FCC forwarded his letter to the station for comment. The station responded that the program had social value and that the listeners liad been warned at the beginning of the program that it contained sensitive and possibly offensive language. ${ }^{173}$

The FCC decided in favor of the complainant witlout imposing formal sanctions upon the station. ${ }^{174}$ The Commission found language in the program to be patently offensive, though not necessarily obscene. ${ }^{175}$ The Counmission also found that the program was aired at a time when children could be expected to be listening. ${ }^{176}$ The FCC concluded that indecent language was not prohibited, only restricted to times when children were not likely to be in the audience. ${ }^{177}$

The Pacifica case eventually worked its way to the Supreme Court. In upholding the FCC's decision, ${ }^{178}$ the Court decided that "indecent" language was not the saine as "obscene" language which is prolibited from being broadcast by 18 U.S.C. $\S 1464 .{ }^{179}$ Nevertleless, the Court held that "indecent" language could be regulated by the government on the public airwaves because individuals have a "right to be let alone" from accidental exposure to indecent inaterial. The Court also said that regardless of the fact that indecent language is protected by the first amendment, the interest of the public in inaintaining its privacy against indecent language outweighs the interest of the originator

172. 438 U.S. 726 (1978).

173. Id. at 730 .

174. Id. (citing Meinorandum Opinion and Order, 56 F.C.C.2d 94, 99 (1975)).

175. Id. at $731-32$ (citing 56 F.C.C.2d at 98 ).

176. Id.

177. Meınorandun Opinion and Order, 59 F.C.C.2d 892 (1976).

178. 438 U.S. at 751 , rev'g 556 F.2d 9 (D.C. Cir. 1977).

179. Id. at 739. 18 U.S.C. $\S 1464$ (1976) provides that "[w]hoever utters any obscene, indecent, or profane language by ineans of radio communication shall be fined not more than $\$ 10,000$ or imprisoned not inore than two years, or both."

While "obscene" refers to inatter appealing to the prurient interest, "indecent" refers to language that does not conform to "accepted standards of morality." 438 U.S. at 740. 
of the material to speak freely. ${ }^{180}$ The listeners or viewers are a captive audience, unable to protect themselves against such a "verbal assault" when they tune in during the middle of programs and iniss any warnings that may have been given earlier. ${ }^{181}$ The Court also stressed the likely harn to children exposed to indecent prograins during the day. ${ }^{182}$ While the Court did not decide whether the Carlin monologue could have been aired at midnight, ${ }^{183}$ it implied that the time, place, and manner of the program would be relevant in deciding whether the station could be disciplined for airing an indecent show. ${ }^{184}$

Thus, the Pacifica opmion demonstrates that once government has the power to determine the content of what is aired, it might use that power to decrease diversity in the nanie of furthering the public interest. The Carlin monologue was of interest to at least a part of the public; the broadcast consisted of a live performance which was recorded $^{185}$ and sold to thousands of consuiners. But the content of the program was objected to by five Justices of the Supreine Court, a majority of the FCC, and one meinber of the radio audience wlio could have easily switched stations or turned off his receiver. Their deternination of social values was inflicted upon the rest of the public. Since one million children watch television as late as one in the inorning, ${ }^{186}$ it is difficult to see how the Court's opimion could result in anything but a ban on "imdecent" programs for the inajority of the adult population. And the Court inanaged this result notwithstanding tlie clear ban on censorship contained in the Communications Act of $1934 .{ }^{187}$ The result in Pacifica hardly promotes diversity, but instead relegates the adult population to liearing only what is fit for children. ${ }^{188}$

Pacifica is not the only instance in which the FCC and the courts have demonstrated proclivity toward censorship rather than diversity. A few years ago, for example, the FCC decided to eliminate so-called "topless radio" shows. About twenty-five radio stations across the country hosted daytime talk shows that often focused on housewives' sexual probleins and relationships. ${ }^{189}$ In 1973 , the shows were very popular, ${ }^{190}$ leading the ratings $\mathrm{m}$ their time slots in several cities. ${ }^{191}$

180. 438 U.S. at 748.

181. Id. at $748-49$.

182. Id. at 749-50.

183. Id at $750 \mathrm{n} .28$.

184. Id. at 750 .

185. Id. at 729 .

186. D. GINSBURG, supra note 64, at 447 (citing Pacifica, 556 F.2d at 14 (D.C. Cir. 1977)).

187. 47 U.S.C. \& 326 (1976).

188. 438 U.S. at 769 (Brennan, J., dissenting).

189. Illinois Citizens Comm. for Broadcasting v. FCC, 515 F.2d 397, 408 (D.C. Cir. 1975)

(Bazelon, C.J., voting to grant rehearing en banc).

190. Id. 
The FCC received a number of complaints about these shows, taped sixty-one hours of "dirty talk shows" as evidence, and cominenced a closed legal proceeding. ${ }^{192}$ FCC Chairperson Dean Burch then spoke at a National Association of Broadcasters convention on the subject. ${ }^{193}$ Chairperson Burch complained about "the prurient trash that is the stock-m-trade of the sex oriented radio talk show."194 He implied that if nothing was done about this problem, the broadcasters would find it difficult to win deregulation from Congress or the FCC. ${ }^{195}$ The predictable result occurred only one day after Burch's speech. A station that syndicated topless radio shows in twenty-one markets ended all sexual discussion on the shows. ${ }^{196}$ A station that continued to broadcast sexual discussions was fined by the FCC, ${ }^{197}$ and the FCC won a court appeal of this decision. ${ }^{198}$ Within three inonths, "topless radio" became extmct in all parts of the country. ${ }^{199}$

FCC censorship has involved more than just stifling arguably immoral forms of entertainment. Former CBS anchorperson Walter Cronkite has questioned the involvement of government in licensing, which he says affects the editorial autonomy of the broadcasting press. ${ }^{200}$ According to Cronkite, high government officials and members of Congress pressure the broadcasters to "report the news the way they would like it reported." 201 One method that Congress uses to pressure news broadcasters is to hold hearings to determine whether existing laws ensure fair news reporting. ${ }^{202}$ In one such hearing Congress investigated alleged attempts to deceive the public through unfair editing processes in the making of CBS' docuinentary, "Selling of the Pentagon."203

In addition to being subjected to Congressional pressure, Walter Cronkite argues that broadcasters face news reporting pressure from the FCC. Members of the public can complain to the FCC, and the

191. D. GinsBuRG, supra note 64 , at 448 .

192. 515 F.2d at 408-09.

193. Id. at 408 .

194. Id.

195. Id.

196. Id. at 408-09.

197. See Sonderling Broadcasting Corp., 41 F.C.C.2d 777 (1973).

198. 515 F.2d at 409-10.

199. Id. at 409 .

200. Cronkite, Introduction to Part III: Points of Conflict - Legal Issues Confronting Media Today, 60 Geo. L.J. 1001 (1972).

201. Id. at 1004 .

202. Id.

203. Subpoenaed Material re Certain TV News Documentary Programs: Hearings Before the Hotse Comm. on Interstate Commerce, 92d Cong., 1st Sess. 1 (1971). - Congress was concerncd that CBS' selective editing of the documentary resulted in an unfair representation of the Defense Department's use of public relation funds. Id. at 235. 
FCC will require the station or network to reply within ten to twenty days. ${ }^{204}$ The broadcaster must take the reply seriously because the FCC may charge the station or the network with violatimg the fairness doctrine. $^{205}$ Cronkite argues that as long as the government has the power to revoke licenses, "[t]he axe lies there temptingly for the use of any enraged administration. We are at the mercy of the whims of politicians and bureaucrats and whether they choose to chop us down or not, the mere existence of their power is an intimidating and constraining threat im being." 206

\section{CONCLUSION}

We are now in the position to inake soine of the same mistakes with cable that have been made with broadcasting. If the governinent can claim that it has an affirmative duty to provide diverse programuning, through access channels or other ineans, the result may be censorship, harassment, and intimidation rather than diversity. Instead of allowing cable viewers to determine prograin content with their subscription dollars, government officials will substitute their judgment of what should be aired for what the public wants to be aired. The teinptations to censor the broadcasting industry have been too great for government to ignore, even though the censors may have had the public's best interests in inind when they created the regulations. Even the FCC's own study concluded that all of its rules and regulations have not succeeded in fostering diversity in television. ${ }^{207}$

The affirmative duty theory represents a noble atteinpt to increase outlets for expression, but the attempted innplementation of this theory in broadcasting has not achieved its intended result. Consequently, the affirmative duty theory should not be extended to cable, and perhaps should be abandoned for all forins of comnunication. Courts and legislatures should return to the earlier interpretations of the first amendment where the guiding principle had been that government should not decide what cannot be said, or what inust be said. The result will not be perfect. Many licensees, and undoubtedly some cable operators, will be uninterested in diversity and will want to prevent some views from being aired. But no ainount of government regulation can change the tendency of humans to ignore opinions in whicl they have no inter-

204. Cronkite, supra note 200, at 1004; see Kalven, Broadcasting, Public Policy and the First Amendment, 10 J.L. \& EcoN. 15, 20-23 (1967).

205. Cronkite, supra note 200 , at 1004.

206. Id. at 1005 . The Commission has the authority to revoke any station license for, among other things, "willful or repeated violation of . . . or repeated failure to observe any provision of this chapter or any rule or regulation of the Commission authorized by [the Communications Act]." 47 U.S.C. § 312(a)(4) (1976).

207. Note, Access and Pay Cable Rates, supra note 1, at 664 n.476. 
est or with which they disagree. By letting the public decide, however, government exhibits more trust in the judgment of the people, which should be the principal object of the first amendment.

Alison Melnick*

- B.A. 1980, Claremont McKenna College; third-year student, Boalt Hall School of Law, University of California, Berkeley. 